\title{
Recommendations on Improving Fiscal and Taxation Policies of Shale Gas Industry in China
}

\author{
Boya Zeng \\ College of Economics, Jinan University, Guangzhou, China \\ Email: 1357089796@qq.com
}

Received 11 March 2016; accepted 16 April 2016; published 19 April 2016

Copyright () 2016 by author and Scientific Research Publishing Inc.

This work is licensed under the Creative Commons Attribution International License (CC BY). http://creativecommons.org/licenses/by/4.0/

(c) (i) Open Access

\begin{abstract}
With the rapid development of economy and the sharp increase of population, energy consumption is increasing and fossil energy reserves are decreasing. It has become an urgent problem to be solved by all the countries that seek for clean and renewable energy. Natural gas is a kind of environment-friendly energy, but conventional natural gas production cannot completely meet the growing demand of natural gas consumption. Shale gas, as a kind of unconventional natural gas, is very rich in our country, which makes the development and utilization of natural gas enter an important field. Therefore, this paper introduces the development situation of shale gas industry in our country and the advantages and disadvantages of the development and utilization of shale gas, and finally discusses the fiscal and taxation policy suitable for the development of shale gas industry in our country by drawing on the successful experience of shale gas development in the USA.
\end{abstract}

\section{Keywords}

Shale Gas, Fiscal Subsidy System, Preferential Tax Policies

\section{Introduction}

As is known to all, coal, oil, natural gas and other fossil fuels have been our main energy since the industrial revolution. They are the material basis for the survival of human society, which play an indispensable role in promoting economic and social development. However, with the rapid development of economy and the sharp increase of population, energy demand is rapidly increasing and reserves are decreasing quickly. Therewith, the pressure to ensure energy supply is getting bigger and bigger and environmental problems become increasingly 
apparent. At present, resource constraints become political, economic, military, diplomatic focus, and meanwhile the world has reached a consensus to cope with global climate change, energy conservation and low-carbon economy, so we now need to find a kind of clean and renewable new energy. Because natural gas discharges $25 \%$ - 30\% carbon dioxide less than oil and $40 \%$ - 50\% less than coal with calorific value [1], there is strong substitutability between natural gas and oil or coal. Thus, in order to protect the environment, we must increase the proportion of natural gas in the constitution of energy consumption in the future.

As shown in Figure 1, the growth rate of consumption of natural gas is much higher than production of natural gas in our country, so the gap between supply and demand is increasingly apparent. Now conventional natural gas production cannot fully meet its growing demand, while shale gas as a new member of natural gas family is a kind of unconventional natural gas resource and reserves are abundant, so it can replace fossil fuels in some areas. Faced with the gap between demand and supply of natural gas, shale gas is bound to become an important source of natural gas.

This article consists of four parts. The first part is about the reserves and distribution of shale gas around the world; the second part is the description of advantages and disadvantages of shale gas in our country; the third part is the important comparison of fiscal and taxation policies of shale gas industry between USA and China and the proposal of problems in fiscal and taxation policies of our country; and the final section is about recommendations on improving fiscal and taxation policies of shale gas industry in our country.

\section{Reserves and Distribution of Shale Gas around the World}

Shale gas is a kind of unconventional natural gas with the main component of methane, and mainly exists in the shale in absorbed or free form. According to the assessment report on shale gas published by US Energy Information Administration (EIA) in 2013, we find that the reserves of global technically recoverable shale gas are 207 trillion cubic meters, which accounts for 32\% of reserves of global technically recoverable natural gas. Among them, our country owns 31.57 trillion cubic meters. In North America, USA holds 18.83 trillion cubic meters and Canada holds 16.23 trillion cubic meters. In Europe, Russia contains 8.07 trillion cubic meters and so on [2]. The detailed case is shown in Figure 2.

\section{Advantages and Disadvantages of Shale Gas in China}

\subsection{Advantages of Shale Gas}

For one thing, the reserves of shale gas are abundant in our country. Shale gas has different types and development

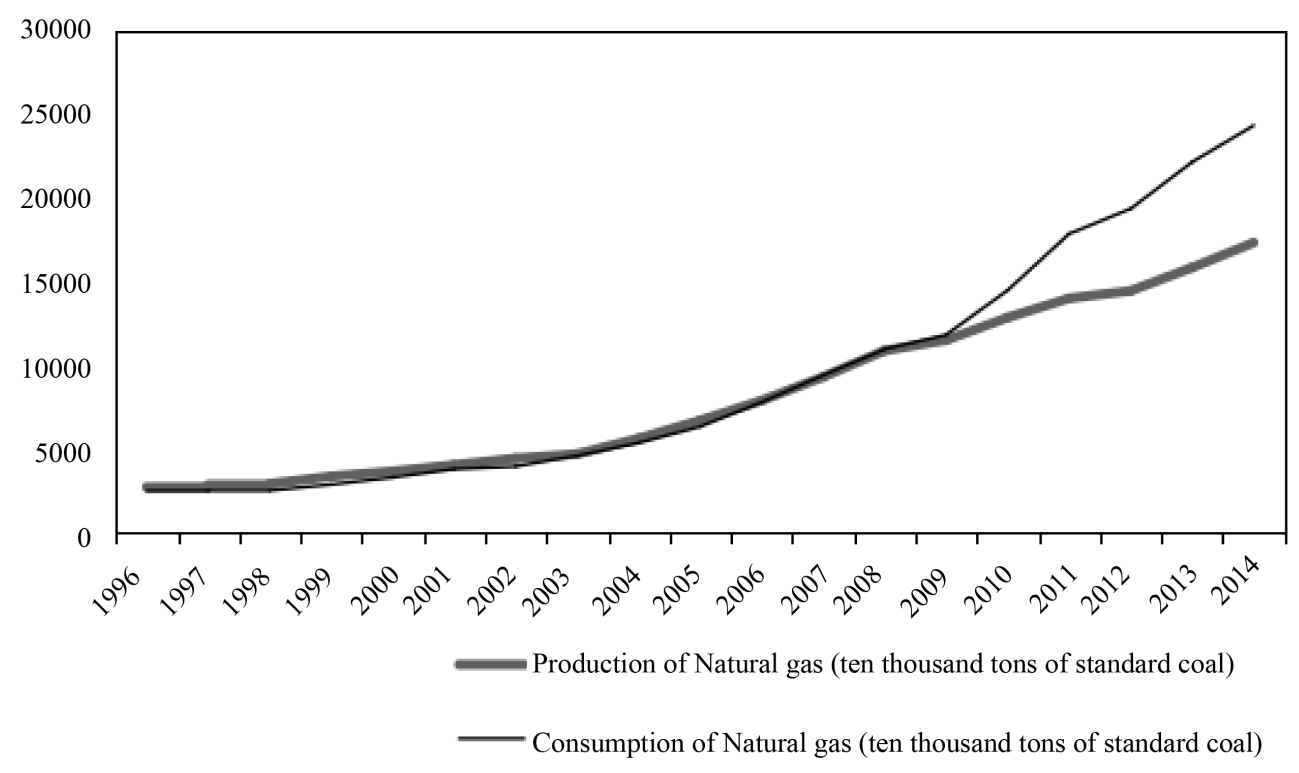

Figure 1. The comparison chart of production and consumption of natural gas between 1996 and 2014 in China. Date source: Chinese statistical yearbook 2015. 


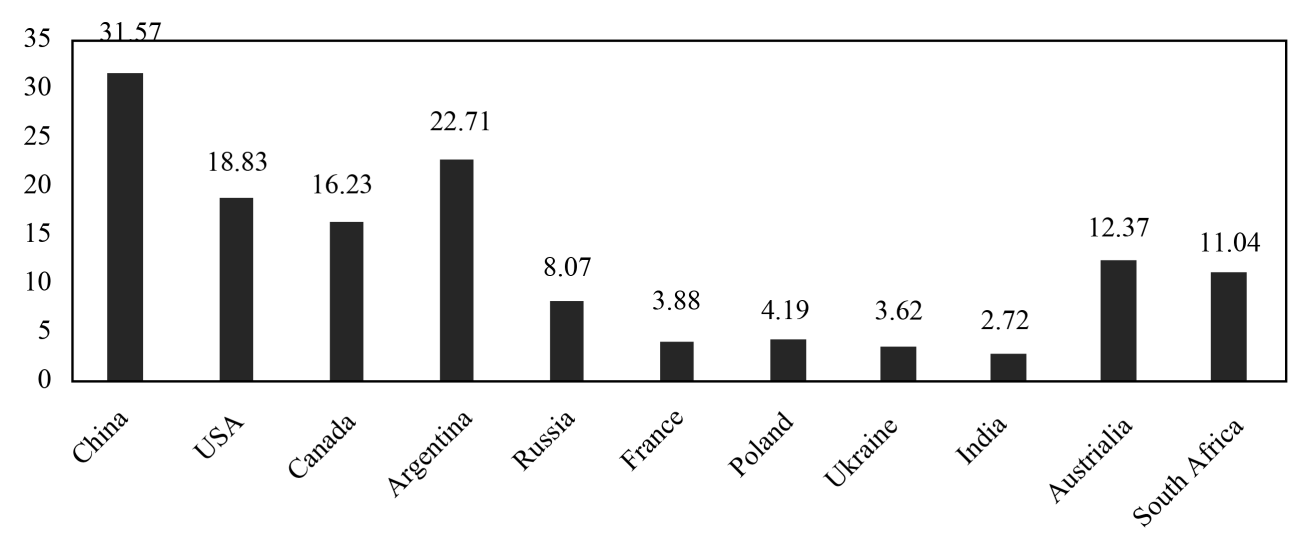

Figure 2. The reserves of global technically recoverable shale gas in 2013 (unit: trillion cubic meters). Date source: the assessment report on shale gas published by EIA in 2013.

potential. According to the data released by EIA in 2013, the reserves of technically recoverable shale gas is 31.57 trillion cubic meters in our country, accounting for $15 \%$ of the reserves of global technically recoverable shale gas and ranking first in the world [2] [3]. For another, Shale gas is a kind of clean and environmentalfriendly resources. Just as mentioned above, carbon dioxide emissions of natural gas is less than oil and coal during the combustion of natural gas, so shale gas also discharges less carbondioxide. Meanwhile shale gas almost has no sulfur, dust and other harmful substances, which makes it have minimal impact on the environment when burning. Shale gas can help protect the environment and improve the quality of the environment radically.

\subsection{Disadvantages of Shale Gas}

Firstly, the development cost of shale gas is high in our country. Compared with conventional natural gas, shale gas reservoir buries deeper and reservoir structure is relatively complex, so we have to meet more difficult questions in the process of exploration and development. For example, the technology we used is mostly high-tech and more complex which requires much more money. Because there are also many unknown factors in the process of exploration and development, these lead to the development cost of shale gas is higher than conventional natural gas, thus obstructing the commercial development of shale gas industry. Secondly, the price of alternative energy sources such as crude oil has declined continuously. Therefore, in the case of a constant energy demand, if the price of crude oil is falling as a substitute for energy, the share of alternative energy in the total energy demand will increase and consumers will have a decline in demand for natural gas including shale gas. Thirdly, the policy on shale gas in our country is not in place on the whole. Some developed countries such as USA started commercial development of shale gas early and has formed a mature legal system. Although in recent years our country has introduced relevant policies to encourage the development and utilization of shale gas, on the whole the policies do not form a complete system. In particular, due to lack of tax incentive measures to encourage the commercialization of shale gas, the stable development of the shale gas industry is restricted.

\section{Comparison and Analysis on Fiscal and Taxation Policies of Shale Gas Industry between USA and China}

\subsection{Comparison on Fiscal and Taxation Policies of Shale Gas Industry}

Fiscal and taxation policies of shale gas industry refer to rules and measures governing the distribution of benefits between the State and shale gas industry in order to develop shale gas industry rationally and orderly, promote the healthy development of shale gas industry, increase efforts to increase natural gas supply, promote energy conservation, and then solve the problem on the supply and demand of natural gas.

\subsection{Analysis on Fiscal and Taxation Policies of Shale Gas Industry}

Compared fiscal and taxation policies of shale gas industry between USA and China, we all know that from the very beginning USA has applied active fiscal policies to support the development of shale gas industry. As 
shown in Table 1, in the early stage of exploration of shale gas, USA applies a large number of fiscal investment to support the shale gas exploration. Especially, in the technology innovation link fiscal support is given greater. Also for the taxation policies, on the one hand, US government encourages investors to shale gas industry investment through the investment tax credit, reducing the taxes on production and raising the cost of tax policies. On the other hand, US government allows shale gas enterprises to take the way of accelerated depreciation during the process of shale gas production to improve the competitiveness of the enterprises.

In recent years, our government has introduced a lot of policies aimed at encouraging rapid development of shale gas industry, like increasing the government's support, which shows the positive attitude and determination of our government to the development and utilization of shale gas. This marks that encouraging fiscal and taxation policies concept for shale gas industry has been formed in our country. The latest data show that China has become the third nation of commercial development of shale gas after USA and Canada. Nevertheless, the development of shale gas is still in the initial stage in our country. Although we have the very rich stock of shale gas, certain technical reserves and government support, fiscal and taxation policies of shale gas industry still exist the following problems in our country.

In general, there are two aspects of problems of fiscal policies. For one thing, the form of fiscal support is excessively single. Throughout current fiscal policies of shale gas industry in our country, the government just only provides one form of fiscal subsidies, and has not yet established various supporting policies system which is complementary and coordinated mutually. So it is easy to appear "trade-off" phenomenon. The single form of fiscal support policy will lead to the lack of incentive means and insufficient support strength. In addition, because the fiscal policies of shale gas industry in our country just aim at production process, we lack specific subsidy policy aiming at the process of exploration and development, technical research, and consumption. For another thing, the fiscal support effort is excessively inadequate. As an example, the cost per unit of shale gas in Fuling block is 1.95 - 3.67 yuan per cubic meter, so we know that only when the sales price is more than 3.67 yuan per cubic meter, the enterprise can balance. As described in the previous section, during the 12th FiveYear-Plan period, our country offers subsidy of 0.4 yuan per cubic meter and then during the 13th Five-YearPlan period the subsidy standard decreases to 0.3 yuan per cubic meter from 2016 to 2018 and 0.2 yuan from 2019 to 2020. In fact, Fuling shale gas price is about 1.41 - 1.74 yuan per cubic meter after deducting the cost of transportation and government subsidy. Compared the date, the loss is still large and enterprises are hard to achieve balance of payments.

Table 1. Evolution of fiscal and taxation policies of shale gas industry in USA [4].

\begin{tabular}{ll} 
Fiscal policies & Taxation policies \\
\hline
\end{tabular}

In the 1970s, the US government set up special fund for the development of basic research and core technology research of shale gas.

In the 1980s, the US government invested more than 6 billion dollars to the development of unconventional gas including shale gas, of which 2 billion is suitable for training and research.

In the 1990s, the US government established research fund of unconventional oil and gas resources including shale gas for related technology research.

In 2004, the US government passed the US Energy Act and the Act prescribes that the government should invest \$45 million a year in research fund in the next 10 years to the unconventional natural gas projects including shale gas.

In addition, the US government can provide investment and financing to shale gas development projects by means of financial allocation, providing loans or loan guarantees.
From the 1970s, the US government began to give tax incentives to the companies who develop shale gas.

In 1980, the US government passed Energy Unexpected Profit Law and the Law stipulates the government should give 3.5 cents per cubic meter tax subsidies of production tax to production of shale gas from 1980 to 1992, meanwhile production tax in the Texas is exempted.

In 1992, the US government passed the Energy Policy Act and the Act formulates that the natural gas producers can deduct percentage depletion preferential amount from total taxable amount in the tax year from 1993. Also, the depletion rate must be not lower than $15 \%$ and the maximum depletion preferential amount must not exceed $65 \%$ of total taxable income.

The US government allows to deduct intangible drilling costs, tangible drilling costs and rental costs, to regard the interests of the company as business income, and to provide depletion allowance to the small producers.

The state government is allowed to provide certain tax incentives for the purpose to the development and utilization of shale gas, such as exemption from tax, reducing the tax rate of mining assets. 
The taxation policies issues of shale gas industry in our country can be considered from three aspects of the value-added tax, resource tax, corporate income tax. Up to now, our tax standards of shale gas is still applicable to natural gas standards. As shown in Table 2, firstly shale gas enterprises should subject to VAT at $13 \%$ of its sales, which is same with conventional natural gas enterprises. But actually shale gas have more energy advantages than conventional natural gas, the requirements of mining technology are much more higher and the cost is much more high, so the current VAT rate is relatively high. Plus, we have not yet developed unified VAT incentives for shale gas, which seriously affect the enthusiasm of shale gas industry investment. Secondly, from November 2011, in our country the resource tax of natural gas including shale gas should be levied ad valorem instead of on the amount. This reform improves the local fiscal revenue and has good role in promoting regulating exploitation and utilization of natural gas. But purposes of resource tax and the distribution of resource tax among different governments in current resource tax provisional regulations are also uncertain, which is likely to cause the unreasonable distribution of resource tax, affect sustainable development of shale gas industry and restrict the role of resource tax in economic construction [5]. Therefore, in order to make resource tax of shale gas be effective tax to regulate the sustainable utilization of shale gas, we need to further improve the resource tax division. Thirdly, our government does not implement certain income tax preferential measures for shale gas enterprises and give preferential income tax rate. Such policy design does not match the purpose of this approach that our country put the shale gas industry into the national strategic emerging industry. Under normal circumstances, it is difficult to achieve profitability for enterprises in the first few years of investment. If there are no corresponding preferential policies, the development of shale gas industry will be severely hampered.

\section{Recommendations on Improving Fiscal and Taxation Policies of Shale Gas Industry in China}

\subsection{Perfecting the Fiscal Subsidy System}

Firstly, our government must increase the capital investment in shale gas exploration. Because there is a certain risk when exploring shale gas, the technical requirements are relatively high and the distribution of shale gas in our country is mainly concentrated in the mountains, it is necessary to provide sufficient fund in the exploration stage. Therefore, the government needs to give support for shale gas enterprises by the way to give fiscal subsidies or provide loans. It is noteworthy that when giving the compensation fund for exploration to shale gas enterprises, the government needs to consider some factors such as buried depth of shale gas and geological conditions. In other words, the government should implement gradient subsidy policy; namely with shale gas's buried depth deeper we should increase subsidies, or according to the different characteristics among the marine, continental and transitional facies, we should establish different subsidy standards. On this account, it promotes exploration and development of shale gas industry of large-scale ground.

Secondly, our government should strengthen support for the innovation of shale gas development technology. As mentioned in Table 1, USA has invested a lot of money on the development of shale gas technology from the 1970s, making American shale gas industry develop in a large scale and shale gas supply continue to increase. This approach changes American natural gas supply pattern. Therefore, the key to the development of shale gas industry lies in the development of core technology. Technological innovation is an important driving force to reduce the cost of shale gas. In view of our country currently only grasping a small part of the shale gas

Table 2. Current fiscal and taxation policies of shale gas industry in China.

\begin{tabular}{|c|c|c|c|}
\hline \multirow{2}{*}{ Fiscal subsidies } & \multicolumn{3}{|c|}{ Major categories of taxes on shale gas } \\
\hline & Value-added tax & Resource tax & Corporate income tax \\
\hline $\begin{array}{l}\text { The central finance must provide direct fiscal subsidies } \\
\text { to all the shale gas enterprises in our country. During the } \\
\text { 12th Five-Year-Plan period, the government offers subsidy } \\
\text { of } 0.4 \text { yuan per cubic meter and then during the } 13 \text { th } \\
\text { Five-Year-Plan period the subsidy standard decreases to } 0.3 \\
\text { yuan per cubic meter from } 2016 \text { to } 2018 \text { and } 0.2 \text { yuan } \\
\text { from } 2019 \text { to } 2020 \text {. At the same time, the local } \\
\text { government can also offer the shale gas enterprises with } \\
\text { appropriate subsidies according to the actual situation. }\end{array}$ & $\begin{array}{l}\text { VAT should be } \\
\text { levied at } 13 \% \text { of } \\
\text { the sales which } \\
\text { shale gas } \\
\text { enterprises gain. }\end{array}$ & $\begin{array}{l}\text { The resource tax } \\
\text { should be levied at } \\
6 \% \text { of the sales. }\end{array}$ & $\begin{array}{l}\text { Based on the taxable } \\
\text { incomes, the corporate } \\
\text { income tax should be } \\
\text { levied at the rate of } 25 \% \text {. }\end{array}$ \\
\hline
\end{tabular}


technology, most mining techniques are not mature in fact, so we must establish diversified fund investment guarantee mechanism and set up special fund to support development of shale gas technology innovation.

Thirdly, our government should increase the price subsidy standard for shale gas industry. For previously calculated shale gas in Fuling block as an example, at present the loss of shale gas enterprise is still big after deducting pipeline transportation fees and government subsidies. It is necessary to improve the government's price subsidy standard to achieve balance under the case of the same gate price and pipeline transportation fees. But the exact price of shale gas is also related to the destination, because the gate price and pipeline transportation fees vary from province to province. Therefore, we also need to consider the introduction of gradient subsidy mechanism based on the price of different gate prices and the level of pipeline transportation fees.

\subsection{Perfecting the Relevant Preferential Tax Policies}

Tax treatment is an important component of the investment environment. Under special circumstances, the preferential tax treatment can make up for shortcomings of other investment conditions to a certain extent. Low tax policy can reduce the overall tax burden of shale gas industry, which has a great impact on the speed of exploration and production of shale gas industry. Since the structural tax reduction was proposed for the first time in the 2008 Central Economic Work Conference, it has been the important means for government to adjust structure and grow steady. Because VAT, resource tax and corporate income tax are the main taxes of energy in our country, relative preferential tax projects of narrow range for shale gas enterprises will limit its development. Therefore, how to use preferential tax policies to promote the development of shale gas industry is our focus here.

Firstly, our government should cut down the VAT rate. Our current VAT rate has $17 \%$ of the standard tax rate, $13 \%$ of the low tax rate and $11 \%, 6 \%$ of two lower tax rates. From Table 2, we can see that the VAT should be levied at $13 \%$ of the sales having no difference with the production and sale of conventional natural gas. Taking the advantages in energy, technology and other factors of shale gas into consideration, we should further reduce the VAT rate of shale gas compared to conventional natural gas. So it is recommended that the VAT rate of shale gas can fall to $11 \%$ of preferential tax rate to promote the rapid development of shale gas industry. But what need to pay attention to is that such preferential tax rate should not be kept. When commercial development of shale gas industry is mature, VAT rate should restore and stay in step with conventional natural gas, which achieving fair competition.

Secondly, our government should deepen the reform of resource tax. As mentioned above, current resource tax provisional regulations has not yet provided the application and allocation of resource tax in our country, therefore it is necessary to clear its purpose in the form of legislation that promoting resource conservation, protecting the ecological environment and keeping sustainable development of shale gas and thereby preventing resource tax from local investment in education, social security expenditure of fiscal expenditure.

Thirdly, our government should relax the scope of corporate income tax. At present, our country has put shale gas industry into the national strategic emerging industries, so there is great strategic significance to make good use of shale gas for protecting national energy security. Considering shale gas industry is still a high-risk and high-investment industry in our country, combined with higher mining cost and much difficulties of development, we should relax the scope of corporate income tax incentives for shale gas industry in order to attract more private enterprises to join the ranks of the development of shale gas. For this reason, on the one hand, the government should reduce research and development (R\&D) expenditure restrictions [5]. Current R\&D expenditure deduction policy is used for specific areas. Its threshold is relatively high and has more constraints, which will make the policy difficult to put in place in the implementation process, and will increase enterprises cost for enjoying R\&D expenses plus deduction. Therefore, these limits should be abolished in shale gas industry and the government should give a certain amount of money returned for those enterprises that is at the loss and cannot enjoy R\&D expenses plus deduction. Or to encourage investment into R\&D technology of shale gas industry, we can increase the proportion of new R\&D expenses plus deduction. On the other hand, the government should refine the provision of accelerated depreciation [5] [6]. Current income tax law has not yet formulated details of accelerated depreciation and has set much threshold conditions, so as to encourage investment in shale gas industry, we should refine supportive provisions of income tax for shale gas industry and according to the asset class provide each type of fixed assets with different depreciation method to make tax-deductible.

\section{References}

[1] Chen, Y.C., Zhao, J. and Tan, J.C. (2012) Opportunities and Risks Faced by China in the Development of the Shale 
Gas and Its Countermeasures. Petroleum Planning \& Engineering, 5, 7-12.

[2] Jiang, H.Y., Ju, B.S., Li, Z.P. and Li, Z.Y. (2014) A Study on the World's Shale Gas Resources Today. Sino-Global Energy, 3, 14-22.

[3] Li, H.X. and Zhang, Y.W. (2015) Global Shale Gas Exploration and Development Today and China's Shale Gas Development Strategy. Sino-Global Energy, 5, 22-29.

[4] Wang, N., Lei, D.F., Liu, X.Y., Du, D. and Yang, J. (2012) Lessons from US and Canadian Shale Gas Industry Policies. International Petroleum Economics, 9, 69-73.

[5] Wang, M.T. (2013) The Study on Fiscal and Taxation Policy of Natural Gas Industry in China. Ph.D. Thesis, China University of Petroleum, China.

[6] Xiao, X.Z. (2011) Fiscal and Taxation Policy Suggestions for the Development of Chinese Strategic Emerging Industries. Public Finance Research, 12, 51-54. 